\title{
SPRU
}

Working Paper Series SWPS 2017-16 (August)

\section{Innovation, Inequality and the Skill Premium}

\author{
Riccardo Leoncini
}

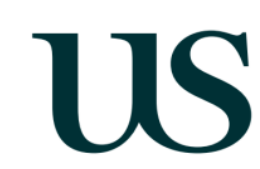




\section{SPRU Working Paper Series (ISSN 2057-6668)}

The SPRU Working Paper Series aims to accelerate the public availability of the research undertaken by SPRU-associated people, and other research that is of considerable interest within SPRU, providing access to early copies of SPRU research.

\section{Editors}

Tommaso Ciarli

Daniele Rotolo

Associate Editors
Karoline Rogge
Paul Nightingale,
Ben Martin, \&
Ohid Yaqub
Tommaso Ciarli
Joe Tidd \&
Carlos Sato
Maria Savona
Andrew Stirling
Caitriona McLeish
Editorial Assistance
Martha Bloom

\section{Contact}

T.Ciarli@sussex.ac.uk

D.Rotolo@sussex.ac.uk

\author{
Area \\ Energy \\ Science, \& Technology Policy \\ Development \\ Technology Innovation Management \\ Economics of Technological Change \\ Transitions \\ Civil Military Interface \\ K.Rogge@sussex.ac.uk \\ P.Nightingale@sussex.ac.uk \\ B.Martin@sussex.ac.uk \\ O.Yaqub@sussex.ac.uk \\ T.Ciarli@sussex.ac.uk \\ J.Tidd@sussex.ac.uk \\ C.E.Y.Sato@sussex.ac.uk \\ M.Savona@sussex.ac.uk \\ A.C.Stirling@sussex.ac.uk \\ C.A.McLeish@sussex.ac.uk
}

\section{Guidelines for authors}

Papers should be submitted to swps@sussex.ac.uk as a PDF or Word file. The first page should include: title, abstract, keywords, and authors' names and affiliations. The paper will be considered for publication by an Associate Editor, who may ask two referees to provide a light review. We aim to send referee reports within three weeks from submission. Authors may be requested to submit a revised version of the paper with a reply to the referees' comments to swps@sussex.ac.uk. The Editors make the final decision on the inclusion of the paper in the series. When submitting, the authors should indicate if the paper has already undergone peer-review (in other series, journals, or books), in which case the Editors may decide to skip the review process. Once the paper is included in the SWPS, the authors maintain the copyright.

\section{Websites}

UoS: www.sussex.ac.uk/spru/research/swps

SSRN: http://www.ssrn.com/link/SPRU-RES.html

IDEAS: ideas.repec.org/s/sru/ssewps.html

Research Gate: www.researchgate.net/journal/2057-6668_SPRU_Working_Paper_Series 


\title{
Innovation, inequality and the skill premium*
}

\author{
Riccardo Leoncini ${ }^{\dagger}$
}

\begin{abstract}
The relationship between innovation and inequality is analysed on a panel of 148 countries for a 50 year span, from 1963-2012. A non linear relationship is found that links innovation to inequality, and which appears to be rather different whether variables representing either input or output of innovative effort are considered. In both cases in fact there appears to be a threshold that once is overcame reverses the relationship. In particular, in the case of innovative inputs a positive relationship with inequality reverses once the threshold is crossed, while the opposite holds for innovative outputs, for which the relationship is initially negative to become positive as, for instance, the number of patents increases over a certain threshold. It is finally possible to exploit these different patterns, to provide a truly innovation-based analysis of the patterns of skill premium for US, France, Germany and Great Britain. In all these case, the ratio of $R \& D$ to Patents shows a robust negative relationship with the skill premium. In particular, when the ratio of $\mathrm{R} \& \mathrm{D}$ to Patents is low (implying a relatively high overall level of appropriability) increasing patterns of the skill premium result. The opposite happens when the ratio is high (implying a relatively low appropriability level), determining a decrease in the skill premium.
\end{abstract}

Keywords: innovation, income inequality, skill premium

JEL classification: O33, D63, J24

*This paper was prepared during my stay at Freiburg Institute for Advanced Studies (FRIAS) of the University of Freiburg, as Senior Fellow (2015-2016) and Marie Curie Fellow of the European Union. Comments and suggestions from participants to a seminar there are kindly acknowledged. I am also thankful to two anonymous referees of the SPRU Working Paper Series for comments and suggestions on an earlier draft.

${ }^{\dagger}$ Freiburg Institute for Advanced Studies (FRIAS), University of Freiburg (D); Research Institute on Sustainable Economic Growth (IRCrES), National Research Council, Milan (I); AlmaMater University of Bologna (I). E-mail: riccardo.leoncini@unibo.it 


\section{Introduction}

It is since the seminal contribution of Kuznets (1955), that the analysis of inequality has become a central topic in the economic literature. As capitalism progresses through successive waves of development, inequality emerges from the structural change due to transition patterns between sectors with different productivity engendered, for instance, by differential innovative capacity. Although Kuznets himself was well aware ${ }^{1}$ of the limits of his model, his theory had a wide impact on the literature on inequality and growth, becoming the centrepiece of the debate aimed at empirically assessing this sort of 'natural' association between growth stages and inequality levels.

The relationships between innovation and inequality has been the object of a very important wave of publications starting from the beginning of the 1980 s, in particular regarding the role of technical change in modifying the pattern of skills required by the economic system. The innovation side of the analysis however was mainly focused on the technological change implied by a particular and pervasive technology (i.e. computers, such as in Krueger (1993); Autor, Katz, and Krueger (1998)). ${ }^{2}$ The relevance of this stream of literature rests mainly on the analysis of how different skills are differently selected by technologies (generating a premium for higher skills). However, a true relationship between innovation and inequality is missing, as this literature implies that skills and technology are complementary, the causal direction is not precisely drawn: skills can in turn bias technological choices of firms 'directing' technological change (Acemoglu, 1998, 2002).

The aim of this paper is to fill this gap, offering a more thorough treatment of the innovative side of the relationships between inequality and technical change. In particular, the overall impact of different aspects of innovative activities will be evaluated, by considering for instance that input (e.g. Research \& Development) and output (e.g. Patents) of innovative activity have a very different impact on the way firms innovate. It will be shown that, depending on the innovative variable chosen, results might change. Moreover, a strong non-linear impact of innovative activity on inequality will be showed, thus making the impact of innovative variables to depend, beside

\footnotetext{
1 "This is perhaps $5 \%$ empirical information and $95 \%$ speculation, some of it possibly tainted by wishful thinking" (Kuznets, 1955, p. 26).

${ }^{2}$ Not only the impact of computrerization was analysed, but also for instance the "batch and continuous-process methods of production" adopted at the beginning of the XX century (Goldin and Katz, 1998).
} 
their typology, also on their level and patterns with which they are combined.

The way in which innovative inputs and outputs combine impacts quite differently the skill premium. It will be thus shown that it is possible to treat the patterns of the skill premium within a more coherently innovation-based frame, which yields coherent results: the more appropriability is looked after, the more inequality rises.

Other elements will also be shown to influence inequality, as recent institutional publications (such as OECD, 2011) support what has now become the conventional view that the recently increasing levels of economic inequality have to do, beside technological change, mainly with a set of not mutually exclusive but reciprocally reinforcing factors that are identified respectively in globalisation and institutions. As innovative activity is differently shaped by the different institutional set-ups (see the different but related literature in Nelson (1993) and Hall and Soskice (2001)), we will advocate to different political frames to mediate the relationship between innovation and inequality. We will also control our results by keeping track of the process of globalisation that so greatly influences the way innovation patterns impact on the wellbeing of people (on these two elements, see also Aghion, Caroli, and Garcìa-Penãlosa (1999)).

This paper's aim is to show that by properly referring to the innovation literature it is possible to give a satisfactory answer to the innovation-inequality causal relationship. Therefore, the research questions of this paper are related to how technical change, globalisation and the institutional frame co-determine different patterns of inequality. In particular, whether different types of innovative activity impact inequality differently, depending on their non-linear causal relationship with inequality. Moreover, the role of institutional factors will be questioned, to show how different political frames impact inequality. Finally, the role of globalisation will be analysed in its different specifications.

The paper is organised as follows. in paragraph 2 the background literature to the paper will be discussed. Paragraph 3 will put forward the main characteristics of the dataset and of the methodology adopted. Paragraph 4 will offer an articulated discussion of the results, and paragraph 5 will provide some concluding remarks. 


\section{Literature review}

\subsection{Inequality and innovative activity}

In order to understand the impact that innovative activity has on inequality we refer to Schumpeter's ideas about the role of innovation in the process of economic growth (Schumpeter, 1934, 1947). Innovation is the engine of economic progress and is the main determinant of the structural dynamics of economic systems, in turn pushing inequality within economic systems. Innovation, at first, act in favour of the first mover (the entrepreneur): she can thus appropriate higher income levels because of her capacity to exploit the innovative ability (i.e. she will be the most talented, or in Schumpeter words a "leader") and thus will increase inequality.

For the sake of this paper, we distinguish between the so called Schumpeter Mark I and Mark II. The former refers to Schumpeter early work (Schumpeter, 1934), in which innovation is brought into a (general) equilibrium setting by the entrepreneur. This behaviour, by destroying the prevalent equilibrium (the so-called creative destruction), confers to the entrepreneur a monopoly profit, that will increase inequality. The process of creative destruction incentivates a wave of imitative behaviour that will cause the innovator's rents to be eroded, thus reducing inequality: the higher the number of imitators, the quicker the catching-up process.

Technological change is thus ultimately responsible for the introduction of more advanced production methods and this in turn determines the adoption of more efficient production processes. This raises productivity and labour income, which in turn reduce inequality. Technological change has therefore both a positive and a negative impact on income asymmetries (e.g. Antonelli and Gehringer, 2013).

Kuznets push-and-pull mechanism would be thus triggered by the variety of innovative behaviour by entrepreneurs. Since Schumpeter in his early model had in mind the entrepreneur, we can expect this to be the result of a new idea that she imposes on society thanks to her leadership. In this case, as no protection for the use of the idea is in place, we can think of this model as pulled by pure knowledge and that this knowledge, embodied in goods, becomes public knowledge and thus becomes available to the stream of imitators, as the dimension of the positive externalities increases with

the amount of knowledge involved. We thus expect that a small amount of knowledge can confer a competitive advantage, while a bigger one is more 
easily appropriable by imitators.

When we instead refer to the late Schumpeter (i.e. Mark II), we must first acknowledge that Schumpeter was witnessing the establishment of giant corporations with huge amount of investments in innovative knowledge, made through dedicated laboratories (Schumpeter, 1947). In this case, innovative knowledge is produced in cost centres with the aim of continuously innovating either products of production processes. The translation of this knowledge into an appropriable innovative commodity cannot be left to the inability of the imitators, but becomes reason for legal protection. In this way, this knowledge can be translated into competitive advantage, but as this knowledge is not produced in very large amounts, still it is possible for other firms to use it and to produce 'laterally' to the impossible to copy protected-by-law innovation. However, as this knowledge increase above a certain threshold, the knowledge becomes so complex that even the availability of the original design can become pretty useless.

Therefore, the relationships between this type of innovative activity (that is well represented by patents) and inequality turns out to be the opposite to the previous one. Indeed, as patents are very little diffused, the knowledge regarding an innovation can be relatively easy to understand and thus even in the presence of a patent, still it is possible to appropriate the results of it by trying to circumvent the barriers to appropriability posed by the patent itself. However, as the number of patents increases, the complexity of the innovation process increases more and more. The many patents that are now defending the original idea are very difficult to overcome, because of the complexity of the technology, the strategic use of the knowledge 'around' it, and the legally binding difficulties that are created by the high number of patents. ${ }^{3}$

\subsubsection{Skill-biased technical change}

A more orthodox stream of literature (Acemoglu, 1998; Goldin and Katz, 1998; Autor, Katz, and Krueger, 1998; Caselli and Coleman, 2002) focused on the so-called skill-biased technical change hypothesis, starting from the seminal work of Krueger (1993) on the relationships between technical change and inequality (a thorough account of which is in Saint-Paul, 2008). It seems

\footnotetext{
${ }^{3}$ This seems confirmed by the fact that the strategic use has led to a recent explosion of patents (Hall, 2004), which are used for reasons that are far from the protection of knowledge as a public good. See, for instance Cohen, Gurun, and Kominers (2016) about the so-called patent trolls.
} 
quite obvious in fact to relate the technological level of a country to the skill level of its workers. As the level of technological change of an economic system increases, firms will need workers with a higher skill level to deal with the new technology (see Levy and Murnane (1992) for an early survey). As the demand for skilled workers increases, and consequently that for unskilled ones decreases, the wage differential is due to diverge. In the period 1970-1989, in front of an average growth of weekly wages of working men in US of about $20 \%$, the least skilled obtained a mere $5 \%$ increase, while the most skilled got a $40 \%$ increase in the same period of time. As a result of this dynamics, in 1989 wages were 15\% higher than in 1970 for the latter category of workers, and 5\% lower for the former one (Juhn, Murphy, and Pierce, 1993).

As technical change was seen predominantly in the use of personal computers, then a skill bias technical change emerged as computers became widely adopted, favouring skilled workers able to work with them (Katz and Murphy, 1992). As a consequence, in the period 1984-89, Krueger (1993) reports estimates that the impact of the increasing utilisation of computer-based technical change increased the wage of the workers using it by 10 to 15 percent. Hence, the diffusion of computers contributed from $1 / 3$ to $1 / 2$ of the rate of return to skilled workers. ${ }^{4}$

However, in spite of this robust empirical analysis, it has been pointed out that, especially in the case of US skill bias is insufficient to induce the downward pressure on low skill wages (Acemoglu, 2002). Moreover, the difficulties in explaining different historical periods and patterns have pushed to sort of reverse the causal pattern by developing models of directed technological change, in which it is the skill bias that drives technology and not the opposite (Acemoglu, 2002).

\footnotetext{
${ }^{4} \mathrm{~A}$ more recent stream of literature has emphasised the role of the content of the different job tasks rather that the 'simple' skilled/unskilled dichotomy in explaining inequality patterns in wages (Autor, Levy, and Murnane, 2003; Acemoglu and Autor, 20111; Autor and Dorn, 2013; Beaudry, Green, and Sand, 2014). The rationale is that technology (i.e. computers) is a substitute of workers employed in routine/non cognitive (in relative terms)/simple (not complex) tasks, and is complementary to workers in non routine/cognitive/complex tasks. If the two types of tasks cannot readily be substituted among them, then the effect of technological change is to reduce the need for routine-based tasks that can be substituted by 'machine programmed rules'. On the contrary, it will increase non routine problem-solving creative and complex tasks. The model proposed explained a large fraction of the shift in demand triggered by decreasing computer prices in the task composition, although with nominally unchanged occupations (Autor, Levy, and Murnane, 2003, p. 1321).
} 
As technology is a crucial element for inequality, (however, see Lemieux (2008) for a skeptical view), other factors must be accounted for in order to fully understand inequality (Acemoglu, 2002; Aghion, Caroli, and GarcìaPenãlosa, 1999). We refer, in particular, to globalisation (Van Reenen, 2011) and to institutional factors (for some recent examples, see for instance Huber and Stephens, 2014; Lamont, Beljean, and Clair, 2014). Therefore, as technical change has been shown to be a necessary but not a sufficient condition to account for the change in income distribution (Aghion, Caroli, and GarciaPenãlosa, 1999; Acemoglu, 2002), other co-factors, such as institutions and globalisation, contribute to determine how the effect of technical change impact inequality.

The empirical work of Marquis, Trehan, and Tantivong (2014), among others, suggests that skilled biased technological progress cannot fully explain the increase in skilled-unskilled wage inequality in the US from the 1970s to the early 1980s. They suggest that a shift in the distribution of human capital across workers can account for a large proportion of increase in skilledunskilled wage inequality in the US. Beladi, Chaudhuri, and Yabuuchi (2008) point to the presence of labour market imperfections. Another important element is related to institutional factors, that in the literature on skill premium translated mainly into several way in which wage dynamics have been compressed by several legislative initiatives (Kristal and Cohen, 2016).

Globalisation levels (in terms of material and immaterial trade) is shown to be a good explanand of wage differentials. On the one side, globalisation implies an exchange between countries with high endowment of low-skilled workers and countries with endowment of high-skilled ones that would increase in the demand for high-skilled labour in the developed nations. This would impact on low-skilled workers in developed countries, with a consequent impact on inequality (e.g. Krueger, 1993). Marjit and Kar (2005) showed that, contrary to the general belief, the emigration of both skilled and unskilled workers from a developing economy can increase skilled/unskilled wage inequality.

\subsection{Main hypotheses}

Our main hypotheses on innovative activity are related to the different impact of different forms of innovative activities.

Indeed, we expect that innovative inputs, since they confer a competitive advantage in small rather than large amount, are related to inequality in the 
following way. When knowledge is produced in small amounts, its appropriability turns out to be high. The reason why this happens is that the less diffused it is an idea, the more it is possible for its producer to keep it. A very small amount of knowledge has a low probability to reach the open market for ideas and be imitated. Thus, innovative knowledge exerts a negative effect on inequality. However, as knowledge increases, it tends to become more and more easily appropriable as more and more people can understand it and benefit from its use. When knowledge is produced in high quantities, the advantages to the producers decrease as there can no longer be benefits from fully appropriating the results of the knowledge produced. Therefore, in this case (i.e. Mark I) we expect a non linear relationship between innovative knowledge and inequality: for lower levels of knowledge we expect a negative relationship, that will reverse when it reaches higher levels.

We thus refer to $R \& D$ as the knowledge available to anybody that can understand it $^{5}$ (as it becomes a public good once it is revealed, see Arrow (1962)), and thus the more it is produced the more it produces positive externalities that can be of benefit for anyone. ${ }^{6}$

The relationships between patents and inequality turns out to be the opposite to the previous one. Indeed, as patents are very few diffused, the knowledge regarding an innovation can be relatively easy to understand and thus even in the presence of a patent, still it is possible to appropriate the results of it by trying to circumvent the barriers to appropriability posed by the patent. However, as the number of patents increase, the complexity of the innovation increases more and more. The many patents that are now defending the original idea are very difficult to overcome, because on the one side of the complexity of the technology, and on the other side by the legally binding difficulties that are created by the high number of patents. ${ }^{7}$

\footnotetext{
${ }^{5}$ Although the problem of knowledge spillover and appropriabilty can be mitigated or not, depending on the absorptive capacity of the would-be imitators (Cohen and Levinthal, 1989), still the role of spillover in innovative activity constitute a powerful engine of growth (such as in Glaeser, Kallal, Scheinkman, and Shleifer, 1992; Henderson, Kuncoro, and Turner, 1995).

${ }^{6}$ The nature of innovative input as public good is the real element characterising the role of, for instance, $R \& D$ in an economic system: because of this, estimates show that realised investments in $R \& D$ are from half to one quarter of optimal amount (Jones and Williams, 1998).

${ }^{7}$ The same should hold for trade marks, as the higher the number of trade marks the more difficult to appropriate innovative results.
} 


\section{Dataset and variables}

The dataset is a longitudinal panel made of 148 countries along a 50 year time span (1963-2012), although because of several missing data the number of observations in some of the regressions is lower than that, especially for R\&D.

The dependent variable of our econometric exercise is economic inequality. The data on economic inequality comes from the joint UNIDO - University of Texas Inequality Project (UTIP-UNIDO). "UTIP's inequality measures are computed as the between-groups component of a Theil T statistic, a very general procedure that can be applied to many sources of data" (Galbraith, 2011, p. 13). The choice of using Theil T statistics therefore results from the possibility of "constructing long and dense time-series of inequality" (which is the title of Conceicao and Galbraith (2000)).

Theil $\mathrm{T}$ statistics allows for the construction of indexes of inequality as it allows for a perfect decomposability of between-group and within-group components. Since there are well specified criteria under which the betweengroup Theil T statistic reasonably represents also the (unobserved) withingroup inequality, the computation of this index is easier and can cover very large samples of countries/years (Galbraith, 2009). Therefore, the Theil T statistic implies that the between-group component describes the contribution of each group to the overall inequality, and moreover, the total (i.e. the sum) of the between-group components constitutes a reasonable lower bound for Theil T statistic for the whole population (technical and non-technical guides are available at http://utip.lbj.utexas.edu/tutorials.html).

For these reasons, this measure is shown to overcome the most important weakness of the most diffused inequality index (the Gini index), which is rarely available for long periods, with the exception of a limited number of highly industrialised countries (e.g. Galbraith, 2011). The advantage is that

coverage in terms of countries and years is far greater, and the uniformity of method yields coefficients that are comparable both through time and across space.

The data on innovative activity (Research and Development, Patents, Trade Marks and Researchers in R\&D) come from the World Development Indicators (WDI) of the World Bank. Also the data for the several control variable on the economic structure (GDP, Population, Herfindhal Index) are from the same source.

The political regimes database was retrieved from the University of Texas. 
It is a dataset that assigns to each country a dummy for each year regarding the prevailing political regime: Dictatorship, Military Dictatorship, Communist, Conservative Democracy, Social Democracy (see for instance, Hsu, 2008).

The indexes on globalisation are taken from the KOF Swiss Economic Institute, that provides indexes for economic, social and political globalisation (Dreher, 2006), and cover a panel of 123 countries for the 1970-2000 time span. KOF indexes are concerned with: "... economic globalisation, characterised as long distance flows of goods, capital and services as well as information and perceptions that accompany market exchanges; political globalisation, characterised by a diffusion of government policies; and social globalisation, expressed as the spread of ideas, information, images and people." (Dreher, 2006, p. 1092).

They are based on several indicators. The political one is made-up of the number of embassies, the membership in international organisations, the participation to UN security council missions and international treaties. The social one by data on personal contacts (such as for instance telephone traffic, international tourism, international letters, internet users, trade in books, number of IKEA and McDonalds shops, and so on). The economic indicator is based on two main series of data, one on actual flows (mainly FDI) and one on restrictions (such as import barriers, tariffs, taxes on international trade and capital account restrictions). ${ }^{8}$

\section{Main results}

The main results are shown in Table 1 where the columns 1 to 4 indicate innovative output (Patents and Trade Marks) and column 5 to 8 innovative inputs (Private and Public R\&D, Researchers in R\&D).

The model used for the innovative outputs is a panel regression with Fixed Effects. The test seems to be appropriate as Patents and Trade Marks appear to show a higher between variance that the within one. Indeed, it seems more likely that patenting activity might be more differentiated among countries because of institutional differences, rather than within countries because of, for instance, sectoral differences. Consequently the Hausman test confirms this hypothesis as the $\chi^{2}(37)=178,18$ for Patents and the

\footnotetext{
${ }^{8}$ The variable on economic globalisation used in this paper, is based solely on data on restrictions to globalisation, as the data on FDI have been used as instrument in the IV estimates.
} 
$\chi^{2}(37)=142,08$ for Trade Marks strongly reject the null that the Random Effect model provides consistent estimates. For innovative inputs the model used is a panel regression with Random Effects. The reason is that in this case, the different nature of the variables implies that they seem to show more within variation as they appear to be less linked to certain specificities (such as the Patents that are highly dependent on institutional factors, such as for instance legal ones). The Hausman test for for $\mathrm{R} \& \mathrm{D}$ is $\chi 2(17)=37,31$ is very weak and is further confirmed by the Breusch Pagan Lagrangian Multiplier test $(\chi 2(6)=34,50)$, while the one for for R\&D Personnel $\left(\chi^{2}(17)=25,96\right)$ do not reject the null that the Random Effect model provides consistent estimates.

Another important preliminary element is that it might well be that innovative activity is itself endogenously determined, as inequality can affect the level of resources devoted to innovative activity. Thus, we have run also IV estimates. ${ }^{9}$ The IV estimates are presented in Table 1 , besides the panel estimates, in columns $1,3,5,7$. The results show that in three cases out of four IV provide a robust estimation of the relationship, as is confirmed by the typical tests on weak and excluded regressor reported at the bottom of Table 1. The only variable for which there appears to be endogeneity is that of Researchers in R\&D, but in this case we could expect such a result as Researchers in R\&D are skilled workers.

The impact of innovative inputs (i.e. $R \& D$ and $R \& D$ Personnel) on inequality is positive (columns 6 and 8 of Table 1), that is an increase in R\&D increases inequality, while innovative outputs (i.e. Patents and Trade Marks) have a negative impact on inequality (columns 2 and 4 of Table 1). Thus, a first important result is that, depending on the type on innovative activity, inequality can either increase or decrease.

As for the rest of the co-variates, the institutional co-variates are sig-

\footnotetext{
${ }^{9}$ We have instrumented our innovative variables with foreign direct investments. Indeed, the literature on the relationship between FDI and inequality does not reach conclusive arguments, neither on the existence of the relationship nor on its direction. Pan-Long (1995); Figini and Görg (2011) find no systematic evidence for developing and developed countries, while the same (inconclusive) results are found for both Europe (Herzer, Nunnenkamp, et al., 2011) and the US (Chintrakarn, Herzer, and Nunnenkamp, 2012). It seems indeed that rather than a direct relationships, several mediators exist between FDI and inequality thus driving the results. In fact, the correlation between Theil $\mathrm{T}$ statistic and FDI is practically nil (-0.013). However, as FDI are one of the component that drives innovative activity, a correlation exist between the innovative variables and FDI, the higher being, obviously, that with R\&D (-0.37), while that with Patents is -0.25 .
} 
nificant and all with negative impact on inequality. However, the impact is quite different, as the Conservative Democracy has the smallest impact on the reduction of inequality, while Communism has the biggest one. The globalisation variables are the economic restriction to trade and the political and social links, respectively. They confirm that a more open political and social environment leads to more inequality, while the role of restriction being positive implies that less economic restrictions are leading to less inequality. The Herfindhal index has a positive impact on inequality, as concentration leads presumably to a higher strategic/troll use of these instruments. Finally, while the impact of population is positive on inequality, higher levels of GDP are beneficial to reducing inequality.

The role of the innovative variables, however, is more complex than it seems a first sight, since also its squared value is statistically significant, and the sign of the relationship is the one expected ex-ante. In fact, its sign indicates that Patents have a non linear relationship with inequality in the form of a upward facing parabola (see Figure 1).

Figure 1: The non linear relationships between patents and inequality

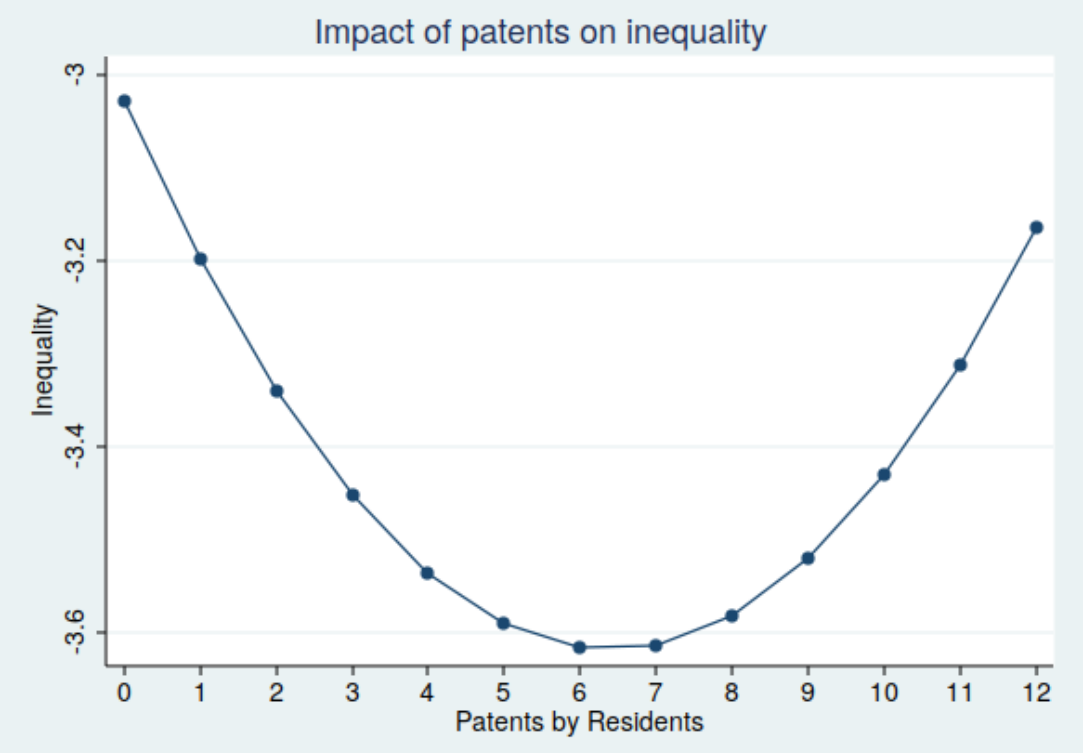

The relationships between Patents and inequality seems thus to sit comfortably well within the Schumpeterian line of reasoning. We seem to be into the Mark II model (Schumpeter, 1947). Here what we have is that the 
more firms invest in their patents portfolio, the more their innovative activity becomes difficult to imitate and the more it is difficult to imitate the more it remains appropriable. Thus a high level of patenting activity implies that the firms can maintain their competitive advantage over the other and if this maintains their level of reward (i.e their monopoly rent) high, it will also maintain a low level of welfare for the rest of the economy, and thus a high level of inequality.

The results for Trade Marks (Column 4 of Table 1) very much mimic those obtained for Patents. Also in this case we have a non linear upward facing relationship with inequality, and all the co-variates have signs comparable in both sign and size to the previously analysed ones. Considering the two terms, the marginal impact of Trade Marks is also smaller than that of Patents. as $1 \%$ increase in its average value increases inequality by $0,12 \%$ while the same increase in Patents produces an increase in inequality of $0,33 \%$.

Figure 2: The non linear relationships between Public R\&D and inequality

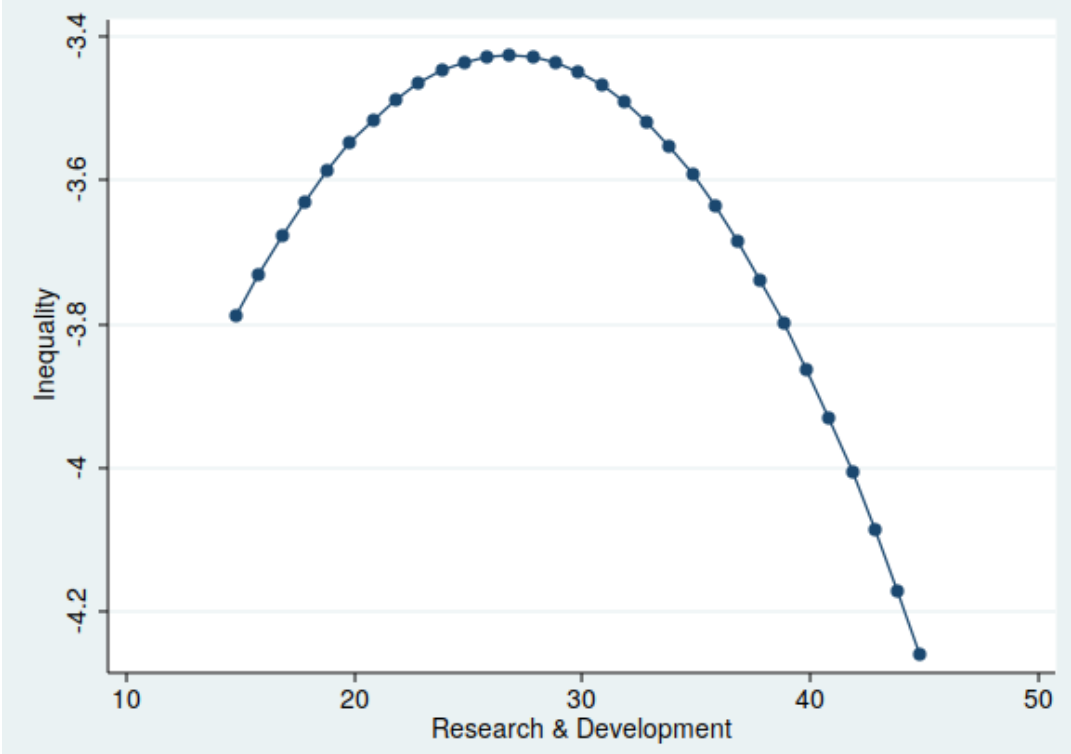

The results for the innovative inputs ( $R \& D$ and Researchers in $R \& D$ ) appear to be less robust than those on innovative output: data on Research and Development are less diffused that those on Patents and Trade Marks: the regression on innovative inputs are performed on about one quarter of those on outputs. 
However, they have common features that are opposite to those described for the output of innovative activity. The two variables show an opposite impact on inequality with respect to the previous ones. They increase inequality up to a certain point, after which its impact starts to decrease. These results are reinforced by the role on economic restrictions, which is statistically significant and negative: opposite to patents, restriction to economic trade are a problem for conducting research, which being less institutionalised, badly needs circulation of knowledge to be favoured at the maximum degree. Tthe role of Conservative Democracy institutional setting is important, as its (negative) impact is the biggest one in the case of the Researchers in R\&D.

Figure 2 shows the graphical relationships between R\&D and inequality (the same figure can be traced for Researchers in R\&D). Again, the relationship between inequality and $R \& D$ is in accordance to the Schumpeterian vision. The knowledge incorporated into the R\&D gets diffused into the techoeconomic system as its level increases, and this is in accord with the vision that as soon as an innovation has earned its monopoly rent, the subsequent wave of imitators erode it through a process of imitation and of diffusion of the innovation within the economic system (Schumpeter, 1934). The erosion of the monopolistic rent in favour of the imitators allows also for an increase of the system welfare, as profits from the innovation get diffused and are beneficial to an increasing number of agents.

These results help clarifying how innovative activity impacts inequality through a coherent supply-driven mechanism, with both the inner nature of the innovative activity and the true dynamics determining the inequality patterns. Indeed, on the one side, innovative activity should not be thought in aggregated terms, but rather in terms of the main elements constituting the socalled knowledge production function (Pakes and Griliches, 1984), Moreover, innovative activity should not be confined to the adoption/diffusion stages only (such as the diffusion of PCs in the economy), but more correctly should be seen in all its components, especially the disembodied ones. From this point of view, that is by looking at a more complete picture, we can also expect firms to adapt their strategies very quickly to changes in the outer environment.

On the other side, firm do not simply adopt superior technologies (such as computers), but work to improve them through complex patterns of both adaptation, marginal and radical modifications. In turn these innovations usually require organisational innovation. Thus, firms are a more complex agent of innovative activity, and this has been (although still partially) 
captured by the different types of innovative activity introduced in this paper. Firms differ in size, capitalisation, industrial sector, position in the value chain, an so on, and all these differences call forth for idiosyncratic behaviours.

\subsection{A new look at the skill premium}

An interesting example of how innovative activity impacts inequality can come by having a look at the most used and known variables of inequality, that is the skill premium. ${ }^{10}$

We have thus calculated the skill premium ${ }^{11}$ and the ratio between $R \& D$ and Patents. This ratio shows high values when $R \& D$ is high and/or patents are low. By looking at the two graphs of Figures 1 and 2, high value of this ratio should imply, coeteris paribus, relatively low levels of inequality, as this ratio would pick values for $R \& D$ at the right of the turning point and values for Patents at the left of the turning point. Contrary wise, low values of the $\mathrm{R} \& \mathrm{D} /$ Patents ratio would imply, coeteris paribus, higher levels of inequality, as in this case R\&D would gravitate on the left of the turning point and Patents on the right of the turning point.

Figure 3 replicate the usual skill premium patten for US from 1962 to 1997 together with the R\&D/Patent ratio. The picture that emerges is quite revealing, as the two variables show a clear and robust inverse correlation. The ratio of $\mathrm{R} \& / \mathrm{D}$ to Patents seems quite able to depict not only the patterns of the skill premium over time, but also its turning points (marked by vertical lines). When the ratio is declining, firms tend to patent more than they research. This in turn allows firms to more than appropriate their innovative effort and thus to benefit from the possible competitive advantage they are able to create with their innovation. This creates a market pressure toward increasing quality products that will benefit skilled workers. The opposite holds when firms are producing more R\&D than patents which being less appropriable allows for imitative efforts to be more successful

\footnotetext{
${ }^{10}$ The data on the skill premium for US are taken from the publicly available Acemoglu dataset, those for France, Germany and Great Britain come from the EU KLEMS Growth and Productivity Accounts: March 2008 Release dataset for the calculation of the skill premium and the OECD STI database for R\&D and Patents.

${ }^{11}$ While the skill premium for US comes from the Acemoglu dataset, the skill premium (SP) for France, Germany and Great Britain has been calculated as the ratio between the proportion of labour compensations (LHS) to the hours worked by high-skilled workers (WHS) and the same proportion for low-skilled worker (LLS and WLS respectively): $S P=\frac{L H S}{W H S} / \frac{L L S}{W L S}$.
} 
Figure 3: Innovative activity and skill premium in US

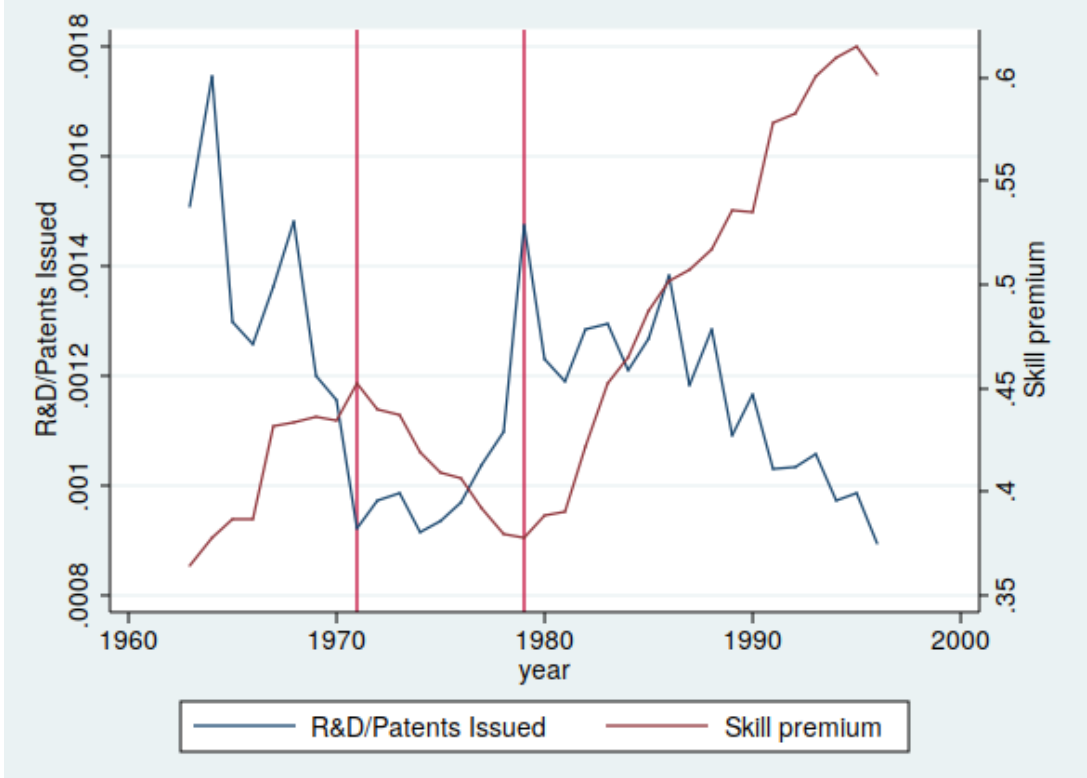

and thus constitute a powerful re-equilibrating element for the wages of less technological firms and thus for their less skilled workers.

The graphs for France (Figure 4), Germany (Figure 5) and Great Britain (Figure 6) follow more similar patterns. Also in these cases it seems quite clear how the skill premium patterns are very much in (inverse) line with the ratio between $R \& D$ and patents. In particular, also for these three other countries there quite clearly appear to be the same characteristics of the US case: the pattern of skill premium is almost everywhere following the inverse one of the innovative activity, and the turning point seems to be even here almost always coincident (as in 2000 for France, 1997/98 for Germany and 2004 for Great Britain).

\section{Conclusions}

This paper provides a novel empirical evidence on the relationships between innovation and inequality. The relevance of this topic being witnessed by the huge and differentiated literature produced over a very long time span, since Kuznets (1955) highlighted the implications for inequality deriving from a 
Figure 4: Innovative activity and skill premium in France

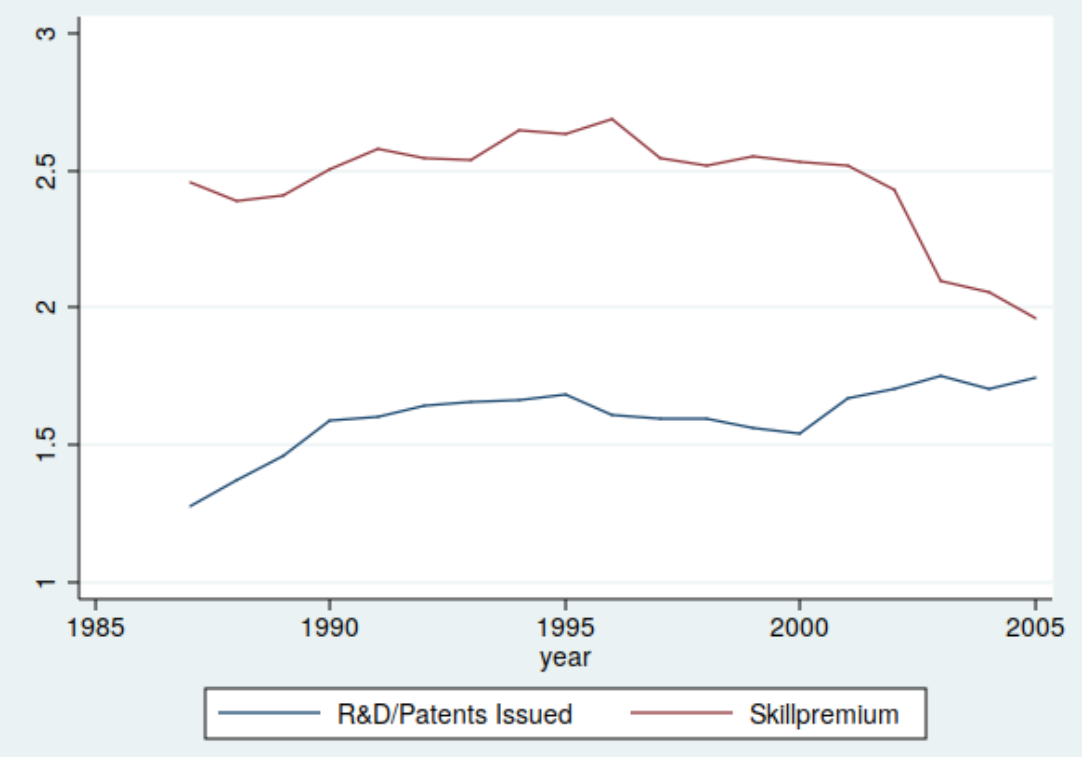

Figure 5: Innovative activity and skill premium in Germany

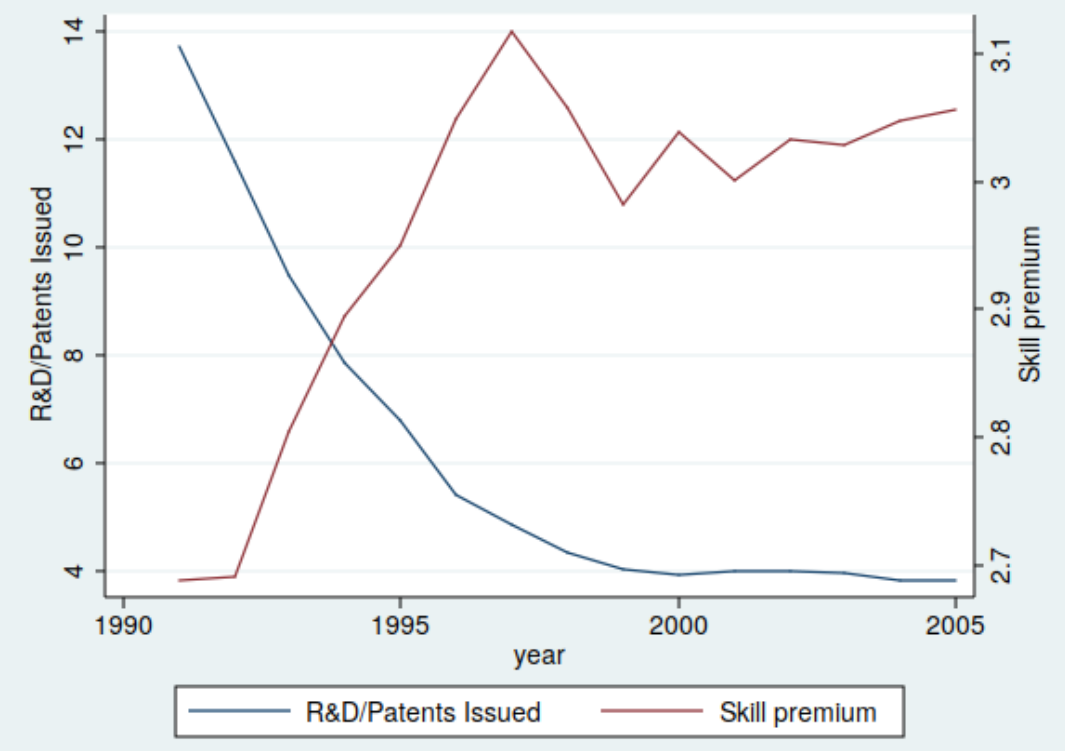


Figure 6: Innovative activity and skill premium in Great Britain

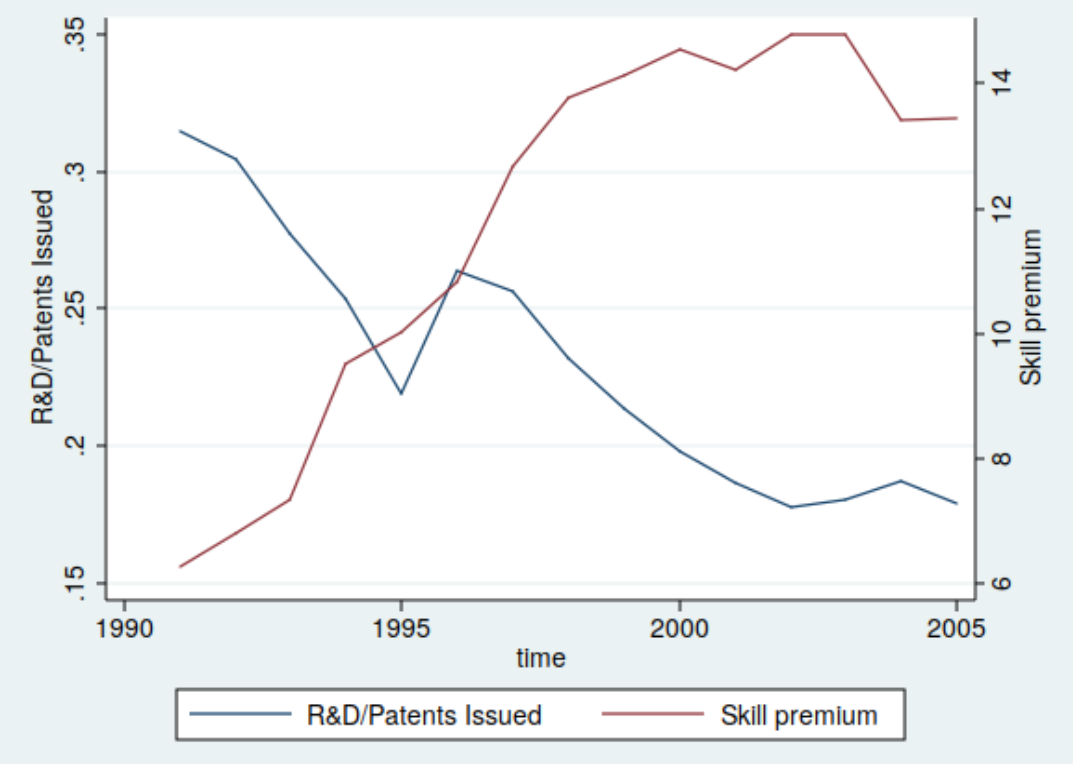

sound theoretical idea. As economies progress, they experience structural changes that in turn affect inequality levels as firms are more or less able to profit from the opportunities the process of change brings about.

The main drivers of this wave of structural change can be identified in the co-evolution of technology, institutional change and globalisation. Technological change determines patterns of structural change through the working of the well-known Schumpetrian mechanism of creative destruction that increases the inequality level in the economy, and that of imitative behaviour, which decreases that level. The two are determined by the degree of appropriability of the technological knowledge that has been shown to have a fundamental role in engendering this kind of dynamics. Depending on the way in which innovation production is considered, either as an input or an output of a knowledge production function, different outcomes result.

The main result of this paper is that a non linear relationship exists between innovation and inequality, and the nature of this non linearity is different whether innovative input or output are considered. Innovative inputs increase inequality up to a point where knowledge spillover allow imitative efforts that, by increasing the productivity level of the systems, decrease inequality. On the contrary, innovative outputs decrease inequality as long 
as it is possible to understand their knowledge content up to a point where the number of patents become so large that either their strategic use or the impossibility to appropriate even part of the knowledge embodied in them, allows only the owner to innovate and consequently to increase the inequality of the system.

Globalisation impact inequality in different ways, as economic restriction seem to affect more the production of innovative inputs than that of output. Also institutions have a role in favouring or not the diffusion of either innovative inputs or outputs. Democratic institutions seem to favour the diffusion of knowledge inputs, more beneficial to reducing inequality, while the opposite seems to hold for less democratic institutional arrangements that favour instead patenting activity. Moreover, this innovative activity seems to follow some well codified model of capitalism, as different patterns emerge by clustering countries according to the type of their innovative performance.

Finally, the model presented allows to gain fresh insights on the patterns of skill premium. Indeed, there seems to be a close relationship between the direction of the skill premium and that of the innovative activity. Moreover, there seems to be a relationships with the way in which the inputs and outputs of innovative activity happen to be combined within an economic system. Hence, skill premium is the result of how the different patterns of innovative activity are produced by the different meshing of innovative inputs and outputs. When the ratio of $R \& D$ to Patenting activity is low, we expect relatively high appropriability for both, thus determining increasing patterns of the skill premium. The opposite happens when the ratio is high, implying relatively low appropriability, thus determining a decrease in the skill premium.

\section{References}

Acemoglu, D. (1998): "Why Do New Technologies Complement Skills? Directed Technical Change and Wage Inequality," Quarterly Journal of Economics, 113(4), 1055-1089.

(2002): "Technical change, inequality, and the labor market," Journal of Economic Literature, 40(1), 7-72.

Acemoglu, D., And D. Autor (20111): "Skills, Tasks and Technolo- 
gies: Implications for Employment and Earnings," in Handbook of Labor Economics, Volume 4b. Elsevier.

Aghion, P., E. Caroli, and C. Garcìa-Penãlosa (1999): "Inequality and economic growth: the perspective of the new growth theories," Journal of Economic Literature, 37(4), 1615-1660.

Antonelli, C., And A. Gehringer (2013): "Innovation and income inequality," Discussion paper, Dpt. of Economics and Statistics, University of Turin.

ARrow, K. (1962): "Economic welfare and the allocation of resources for invention," in The Rate and Direction of Inventive Activity: Economic and Social Factors, pp. 609-626. Princeton University Press.

Autor, D. H., And D. Dorn (2013): "The growth of low-skill service jobs and the polarization of the US labor market," American Economic Review, 103(5), 1553-1597.

Autor, D. H., L. F. Katz, and A. B. Krueger (1998): "Computing inequality: have computers changed the labor market?," Quarterly Journal of Economics, 113(4), 1169-1213.

Autor, D. H., F. Levy, and R. J. Murnane (2003): "The Skill Content of Recent Technological Change: An Empirical Exploration," Quarterly Journal of Economics, 118(4), 1279-1333.

Beaudry, P., D. A. Green, and B. M. Sand (2014): "The Declining Fortunes of the Young since 2000," American Economic Review, 104(5), $381-86$.

Beladi, H., S. Chaudhuri, and S. Yabuuchi (2008): "Can International Factor Mobility Reduce Wage Inequality in a Dual Economy?*," Review of International Economics, 16(5), 893-903.

Caselli, F., and W. J. Coleman (2002): "The US technology frontier," American Economic Review, 92(2), 148-152.

Chintrakarn, P., D. Herzer, and P. Nunnenkamp (2012): "FDI and income inequality: Evidence from a panel of US states," Economic Inquiry, 50(3), 788-801. 
Cohen, L., U. G. Gurun, and S. D. Kominers (2016): "The growing problem of patent trolling," Science, 352(6285), 521-522.

Cohen, W., and D. Levinthal (1989): "Innovation and learning: The two faces of R\&D," Economic Journal, 99, 569-596.

Conceicao, P., and J. K. Galbraith (2000): "Constructing long and dense time series of inequality using the Theil statistic.," Eastern Economic Journal, 26(1), 61-74.

DreHer, A. (2006): "Does globalization affect growth? Evidence from a new index of globalization," Applied Economics, 38(10), 1091-1110.

Figini, P., AND H. GÖRG (2011): "Does foreign direct investment affect wage inequality? An empirical investigation," The World Economy, 34(9), $1455-1475$.

Galbraith, J. K. (2009): "Inequality, unemployment and growth: New measures for old controversies," Journal of Economic Inequality, 7(2), 189-206.

Galbraith, J. K. (2011): "Inequality and economic and political change: a comparative perspective," Cambridge Journal of Regions, Economy and Society, 4, 13-27.

Glaeser, E., H. Kallal, J. Scheinkman, and A. Shleifer (1992): "Growth in cities," Journal of Political Economy, 100, 1126-1152.

Goldin, C., And L. F. Katz (1998): "The origins of technology-skill complementarity," Quarterly Journal of Economics, 113(3), 693-732.

Hall, B. H. (2004): "Exploring the patent explosion," Journal of Technology Transfer, 30(1-2), 35-48.

Hall, P. A., And D. Soskice (eds.) (2001): Varieties of Capitalism: The Institutional Foundations of Comparative Advantage. Oxford University Press.

Henderson, V., A. Kuncoro, and M. Turner (1995): "Industrial development in cities," Journal of Political Economy, 103, 1067-1090. 
Herzer, D., P. Nunnenkamp, et AL. (2011): "FDI and income inequality: Evidence from Europe," Discussion paper, Kiel Working Paper.

Hsu, S. (2008): "The Effect of Political Regimes on Inequality, 1963-2002," Discussion paper, University of Texas Inequality Project, UTIP Working Paper No. 53.

Huber, E., And J. D. Stephens (2014): "Income inequality and redistribution in post-industrial democracies: demographic, economic and political determinants," Socio-Economic Review, 12(2), 245-267.

Jones, C., And J. Williams (1998): "Measuring the Social Return to R\&D," Quarterly Journal of Economics, 113, 1119-1135.

Juhn, C., K. M. Murphy, and B. Pierce (1993): "Wage inequality and the rise in returns to skill," Journal of Political Economy, 101(3), 410-442.

Katz, L. F., And K. M. Murphy (1992): "Changes in relative wages, 1963-1987: supply and demand factors," Quarterly Journal of Economics, 107(1), 35-78.

KRISTAL, T., And Y. COHEN (2016): "The causes of rising wage inequality: the race between institutions and technology," Socio-Economic Review, pp. $1-26$.

Krueger, A. B. (1993): "How computers have changed the wage structure: evidence from microdata," Quarterly Journal of Economics, 108(1), 33-60.

Kuznets, S. (1955): "Economic growth and income inequality," American Economic Review, 45(1), 1-28.

Lamont, M., S. Beljean, And M. Clair (2014): "What is missing? Cultural processes and causal pathways to inequality," Socio-Economic Review, 12(3), 573-608.

Lemieux, T. (2008): "The changing nature of wage inequality," Journal of Population Economics, 21(1), 21-48.

Levy, F., And R. J. Murnane (1992): "US earnings levels and earnings inequality: A review of recent trends and proposed explanations," Journal of Economic Literature, 30(3), 1333-1381. 
MARJit, S., And S. KAR (2005): "Emigration and wage inequality," Economics Letters, 88(1), 141-145.

Marquis, M. H., B. Trehan, and W. Tantivong (2014): "The wage premium puzzle and the quality of human capital," International Review of Economics \& Finance, 33, 100-110.

Nelson, R. (ed.) (1993): National Innovation Systems. A Comparative Analysis. Oxford University Press, New York.

OECD (2011): Divided We Stand - Why Inequality Keeps Rising. OECD, Paris.

Pakes, A., And Griliches (1984): "Patents and R\&D at the Firm Level: A First Look," in REDD, Patents, and Productivity, ed. by Z. Griliches, pp. 55-72. University of Chicago Press.

PAN-LONG, T. (1995): "Foreign direct investment and income inequality: further evidence," World Development, 23(3), 469-483.

Saint-Paul, G. (2008): Innovation and Inequality: How does Technical Progress Affect Workers? Princeton University Press, Princeton.

Schumpeter, J. A. (1934): The Theory of Economic Development. Harvard University Press, Cambridge, MA.

(1947): Capitalism, Socialism, and Democracy. Harper \& Brothers Publishers, New York and London.

VAN ReEnen, J. (2011): "Wage inequality, technology and trade: 21st century evidence," Labour Economics, 18(6), 730-741. 
Table 1: Impact of innovative variables on income inequality

\begin{tabular}{|c|c|c|c|c|c|c|c|c|}
\hline & \multicolumn{2}{|c|}{ Patents } & \multicolumn{2}{|c|}{ Trade Marks } & \multicolumn{2}{|c|}{ "Private R\&D } & \multicolumn{2}{|c|}{ "Researchers in R\&D } \\
\hline & $\begin{array}{l}\text { IV } \\
(1)\end{array}$ & $\begin{array}{c}\text { Panel } \\
(2)\end{array}$ & $\begin{array}{l}\text { IV } \\
(3)\end{array}$ & $\begin{array}{c}\text { Panel } \\
(4)\end{array}$ & $\begin{array}{l}\text { IV } \\
(5)\end{array}$ & $\begin{array}{c}\text { Panel } \\
(6)\end{array}$ & $\begin{array}{l}\text { IV } \\
(7)\end{array}$ & $\begin{array}{c}\text { Panel } \\
(8)\end{array}$ \\
\hline lPAT & $\begin{array}{c}-0.747^{* * *} \\
(0.271)\end{array}$ & $\begin{array}{c}-0.184^{* * *} \\
(0.0609)\end{array}$ & & & & & & \\
\hline IPATsq & & $\begin{array}{c}0.0144 * * \\
(0.00647)\end{array}$ & & & & & & \\
\hline lTMK & & & $\begin{array}{l}2.296^{*} \\
(1.356)\end{array}$ & $\begin{array}{c}-0.279^{* *} \\
(0.121)\end{array}$ & & & & \\
\hline lTMKsq & & & & $\begin{array}{c}0.0237^{* *} \\
(0.0104)\end{array}$ & & & & \\
\hline $\mathrm{lR} \& \mathrm{D}$ & & & & & $\begin{array}{c}0.328^{* *} \\
(0.146)\end{array}$ & $\begin{array}{c}0.137^{*} \\
(0.0799)\end{array}$ & & \\
\hline IR\&Dsq & & & & & & $\begin{array}{c}-0.00256^{*} \\
(0.00143)\end{array}$ & & \\
\hline IRES & & & & & & & $\begin{array}{c}-7,72 \\
(20.67)\end{array}$ & $\begin{array}{l}1.051^{*} \\
(0.637)\end{array}$ \\
\hline lRESsq & & & & & & & & $\begin{array}{c}-0.0949 * * \\
(0.0480)\end{array}$ \\
\hline DICT & $\begin{array}{c}-1.433^{* * *} \\
(0.406)\end{array}$ & $\begin{array}{c}-0.576^{*} \\
(0.342)\end{array}$ & $\begin{array}{c}0,671 \\
(0.638)\end{array}$ & $\begin{array}{l}-0,235 \\
(0.320)\end{array}$ & & $\begin{array}{c}0.565^{* *} \\
(0.278)\end{array}$ & & $\begin{array}{c}0,686 \\
(0.649)\end{array}$ \\
\hline MDIC & $\begin{array}{c}-1.495^{* * *} \\
(0.450)\end{array}$ & $\begin{array}{c}-0,464 \\
(0.322)\end{array}$ & $\begin{array}{c}0,133 \\
(0.397)\end{array}$ & $\begin{array}{l}-0,172 \\
(0.283)\end{array}$ & & & & $\begin{array}{c}0,912 \\
(0.826)\end{array}$ \\
\hline COMM & $\begin{array}{c}-3.407^{* * *} \\
(0.616)\end{array}$ & $\begin{array}{c}-1.683^{* * *} \\
(0.335)\end{array}$ & $\begin{array}{c}5,103 \\
(4.029)\end{array}$ & $\begin{array}{c}-1.126^{* * *} \\
(0.390)\end{array}$ & & & & \\
\hline DEMO & $\begin{array}{c}-1.485^{* * *} \\
(0.462)\end{array}$ & $\begin{array}{c}-0,392 \\
(0.299)\end{array}$ & $\begin{array}{c}1,041 \\
(0.731)\end{array}$ & $\begin{array}{c}-0,0416 \\
(0.288)\end{array}$ & & $\begin{array}{c}-0,0743 \\
(0.272)\end{array}$ & & $\begin{array}{c}-0,605 \\
(0.417)\end{array}$ \\
\hline lEC REST & $\begin{array}{l}0,0155 \\
(0.212)\end{array}$ & $\begin{array}{c}0.427^{* *} * \\
(0.187)\end{array}$ & $\begin{array}{l}-0,258 \\
(0.410)\end{array}$ & $\begin{array}{c}0,27 \\
(0.179)\end{array}$ & $\begin{array}{c}-0.550^{* *} \\
(0.281)\end{array}$ & $\begin{array}{c}-0.446^{* *} \\
(0.224)\end{array}$ & $\begin{array}{c}0,146 \\
(1.836)\end{array}$ & $\begin{array}{c}-0.494^{*} \\
(0.264)\end{array}$ \\
\hline ISOC KOF & $\begin{array}{c}0.485^{* * *} \\
(0.123)\end{array}$ & $\begin{array}{c}0,409 \\
(0.251)\end{array}$ & $\begin{array}{l}-0,587 \\
(0.755)\end{array}$ & $\begin{array}{l}0.468^{*} \\
(0.261)\end{array}$ & $\begin{array}{l}-0,422 \\
(0.322)\end{array}$ & $\begin{array}{l}-0,413 \\
(0.444)\end{array}$ & $\begin{array}{c}-3,747 \\
(10.03)\end{array}$ & $\begin{array}{c}-0,191 \\
(0.348)\end{array}$ \\
\hline IPOL KOF & $\begin{array}{c}0.311^{* *} \\
(0.138)\end{array}$ & $\begin{array}{c}0,169 \\
(0.148)\end{array}$ & $\begin{array}{r}-0,0741 \\
(0.275)\end{array}$ & $\begin{array}{c}0,00834 \\
(0.168)\end{array}$ & $\begin{array}{c}0,0757 \\
(0.239)\end{array}$ & $\begin{array}{r}-0,0882 \\
(0.281)\end{array}$ & $\begin{array}{c}0,586 \\
(2.100)\end{array}$ & $\begin{array}{l}-0,114 \\
(0.228)\end{array}$ \\
\hline IPOP & $\begin{array}{c}1.911^{* * * *} \\
(0.368)\end{array}$ & $\begin{array}{c}1.239^{* * *} \\
(0.456)\end{array}$ & $\begin{array}{c}-0,851 \\
(1.323)\end{array}$ & $\begin{array}{c}0.957^{* *} \\
(0.396)\end{array}$ & $\begin{array}{c}0,632 \\
(0.665)\end{array}$ & $\begin{array}{l}0.326^{*} \\
(0.181)\end{array}$ & $\begin{array}{c}11,81 \\
(34.78)\end{array}$ & $\begin{array}{r}-0,0221 \\
(0.135)\end{array}$ \\
\hline lGDP & $\begin{array}{c}0,103 \\
(0.178)\end{array}$ & $\begin{array}{c}-0.952^{\text {**** }} \\
(0.211)\end{array}$ & $\begin{array}{c}-1.734^{* *} \\
(0.865)\end{array}$ & $\begin{array}{c}-0.931^{* * *} \\
(0.191)\end{array}$ & $\begin{array}{c}-1.009^{*} \\
(0.520)\end{array}$ & $\begin{array}{c}-0.385^{*} \\
(0.225)\end{array}$ & $\begin{array}{c}3,954 \\
(10.02)\end{array}$ & $\begin{array}{r}-0,0262 \\
(0.165)\end{array}$ \\
\hline lHERF & $\begin{array}{c}0.171 \\
(0.149)\end{array}$ & $\begin{array}{c}0.339^{* * *} \\
(0.128)\end{array}$ & $\begin{array}{c}0.796^{* *} \\
(0.372)\end{array}$ & $\begin{array}{c}0.261^{* *} \\
(0.127)\end{array}$ & $\begin{array}{c}0,292 \\
(0.251)\end{array}$ & $\begin{array}{r}-0,0357 \\
(0.262)\end{array}$ & $\begin{array}{c}0,151 \\
(1.632)\end{array}$ & $\begin{array}{l}-0,172 \\
(0.287)\end{array}$ \\
\hline Cons & & $\begin{array}{c}-10.31^{* *} \\
(4.137)\end{array}$ & & $\begin{array}{c}-6.585^{*} \\
(3.869)\end{array}$ & & $\begin{array}{c}0,404 \\
(2.761)\end{array}$ & & $\begin{array}{l}-0.592 \\
(3.781)\end{array}$ \\
\hline $\mathrm{N}$ & 1064 & 1117 & 1092 & 1153 & 299 & 315 & 269 & 288 \\
\hline $\begin{array}{l}\text { Under Ident Test } \\
\text { Weak Ident Test } \\
\text { Endog Regressor }\end{array}$ & $\begin{array}{c}9.527 \\
(0.002) \\
9.512 \\
15.455 \\
(0.001)\end{array}$ & & $\begin{array}{c}3.202 \\
(0.074) \\
3.177 \\
24.334 \\
(0.000)\end{array}$ & & $\begin{array}{c}9.045 \\
(0.002) \\
9.120 \\
6.923 \\
(0.008)\end{array}$ & & $\begin{array}{c}0.156 \\
(0.693) \\
0.151 \\
4.015 \\
(0.045)\end{array}$ & \\
\hline
\end{tabular}

Robust standard errors in parentheses

${ }^{*} p<0.10,{ }^{* *} p<0.05,{ }^{* * *} p<0.01$ 


\section{Recent papers in the SPRU Working Paper Series:}

\section{August}

User-Intermediaries and the Local Embedding of Low Carbon Technologies. Jake Barnes

\section{July}

Who Gains from High-Tech Growth? High-Technology Multipliers, Employment and Wages in Britain. Neil Lee and Stephen Clarke

June

Measures, Drivers and Effects of Green Employment: Evidence from US Local Labor Markets, 2006-2014. Francesco Vona, Giovanni Marin and Davide Consoli

Structural Changes and Growth Regimes. Tommaso Ciarli, André Lorentz, Marco Valente and Maria Savona

Explaining Sociotechnical Transitions: A Critical Realist Perspective. Steve Sorrell

Social Innovation, Democracy and Makerspaces. Adrian Smith

Adoption and Diffusion of Micro-Grids in Italy. An Analysis of Regional Factors Using Agent-Based Modelling. Francesco Pasimeni

\section{May}

The Measurement of Synergy in Innovation Systems: Redundancy Generation in a Triple Helix of University-Industry-Government Relations. Loet Leydesdorff, Henry Etzkowitz, Inga Ivanova and Martin Meyer

\section{March}

Inclusive Innovation and Rapid Sociotechnical Transitions: The Case of Mobile Money in Kenya. Elsie Onsongo and Johan Schot

Does Managerial Experience Affect Strategic Change? Matte Hartog and Frank Neffke Coworker Complementarity. Frank Neffke

\section{Suggested citation:}

Riccardo Leoncini (2017). Innovation, Inequality and the Skill Premium. SPRU Working Paper Series (SWPS), 2017-16: 1-24. ISSN 2057-6668. Available at: www.sussex.ac.uk/spru/swps2017-16

\section{SPRU - Science Policy Research Unit}

University of Sussex

Falmer, Brighton, BN1 9SL,United Kingdom

SWPS Website: www.sussex.ac.uk/spru/research/swps

SPRU Website: www.sussex.ac.uk/spru

SPRU Twitter: @SPRU 